\title{
Multiplex ligatiofüggő szondaamplifikáció az onkohematológiai kutatásban és diagnosztikában
}

\author{
Kiss Richárd dr. ${ }^{1}$ - Kosztolányi Szabolcs dr. ${ }^{2}$ - Gángó Ambrus dr. ${ }^{1}$ \\ Szuhai Károly dr. ${ }^{3}$ - Bödör Csaba dr. ${ }^{1}$ - Alpár Donát dr. ${ }^{1}$
}

\author{
${ }^{1}$ Semmelweis Egyetem, Általános Orvostudományi Kar, I. Patológiai és Kísérleti Rákkutató Intézet, \\ MTA-SE Lendület Molekuláris Onkohematológia Kutatócsoport, Budapest \\ ${ }^{2}$ Pécsi Tudományegyetem, Általános Orvostudományi Kar, Klinikai Központ, I. Belgyógyászati Klinika, Pécs \\ ${ }^{3}$ Department of Cell and Chemical, Leiden University Medical Center, Leiden, Hollandia
}

\begin{abstract}
A malignus hematológiai betegségek kialakulását, progresszióját, illetve terápiával szemben mutatott rezisztenciáját kísérő genetikai eltéréseket ma már egyre alaposabban ismerjük. A klinikailag releváns abnormalitásoknak a mindennapi diagnosztika keretein belül való célzott kimutatása gyors, megbízható és költséghatékony módszereket igényel. A multiplex ligatiofüggő szondaamplifikáció a genomikus kópiaszám-eltérések vizsgálatának hatékony eszköze, melylyel 55-60 lókusz egyidejúleg analizálható. Az eljárás lehetőséget nyújt prognosztikai és prediktív markerek átfogó felderítésére, így alkalmazása hatékonyan kombinálható a kariotipizálással és fluoreszcencia in situ hibridizációval, melyek jelenleg a legelterjedtebb diagnosztikus technikák citogenetikai aberrációk kimutatására. Ezenkívül a módszer képes a metilációs státusz célzott meghatározására és specifikus mutációk detektálására is, 24 órán belül eredményt szolgáltatva. Az alábbiakban bemutatjuk a multiplex ligatiofüggő szondaamplifikáció technikai hátterét, összefoglaljuk előnyeit és korlátait, valamint megbeszéljük az onkohematológiai kutatásban és diagnosztikában betöltött szerepét. Végezetül, az új generációs szekvenáláshoz kapcsolódó, közelmúltbeli technológiai újítások fényében tárgyaljuk a módszerben rejlő jövőbeli lehetőségeket.
\end{abstract}

Orv Hetil. 2018; 159(15): 583-592.

Kulcsszavak: multiplex ligatiofüggő szondaamplifikáció, onkohematológia, diagnosztika

\section{Multiplex ligation-dependent probe amplification in oncohematological diagnostics and research}

\begin{abstract}
Genetic abnormalities associated with the development, progression and treatment resistance of hematological malignancies are extensively characterized. Rapid, reliable and cost-efficient techniques are needed to screen the clinically relevant aberrations in routine diagnostics. Multiplex ligation-dependent probe amplification is an efficient tool to analyze genomic copy number aberrations at 55-60 different genomic loci. The method allows the profiling of prognostic and predictive markers; thus, it can efficiently be combined with karyotyping and fluorescence in situ hybridization, the most commonly used diagnostic techniques to detect cytogenetic lesions. Furthermore, the method can interrogate methylation status and unravel point mutations at specific sites, providing results in 24 hours. Here, we describe the technical background of multiplex ligation-dependent probe amplification, summarize its advantages and limitations as well as discuss its role in oncohematological diagnostics and research. Finally, future outlook is provided, with emphasis on recent technological advances related to next-generation sequencing.
\end{abstract}

Keywords: multiplex ligation-dependent probe amplification, oncohematology, diagnostics

Kiss R, Kosztolányi Sz, Gángó A, Szuhai K, Bödör Cs, Alpár D. [Multiplex ligation-dependent probe amplification in oncohematological diagnostics and research]. Orv hetil. 2018; 159(15): 583-592.

(Beérkezett: 2018. január 10.; elfogadva: 2018. február 8.) 


\section{Rövidítések}

$\mathrm{ALL}=$ akut lymphoblastos leukaemia; CLL = krónikus lymphocytás leukaemia; $\mathrm{CML}=$ krónikus myeloid leukaemia; FISH = fluoreszcencia in situ hibridizáció; iAMP21 = a 21-es kromoszóma intrakromoszomális amplifikációja; MCL = köpenysejtes lymphoma; MLPA = (multiplex ligation-dependent probe amplification) multiplex ligatiofüggő szondaamplifikáció; MS-MLPA = metilációszenzitív MLPA; NGS = $($ nextgeneration sequencing) új-generációs szekvenálás; $\mathrm{PCR}=$ polimeráz-láncreakció

\section{A genetikai eltérések jelentősége onkohematológiai kórképekben}

Az onkohematológiai kórképek vizsgálata számos alkalommal járt élen a malignus betegségek hátterében meghúzódó genetikai folyamatok felderítésében [1]. Ennek oka egyrészt a minták viszonylag könnyú hozzáférhetőségében, másrészt a szolid tumorokhoz viszonyítva tipikusan alacsonyabb számú genetikai elváltozás jelenlétében valószínúsíthető [2]. A krónikus myeloid leukaemia (CML) volt például az első olyan rosszindulatú betegség, melyhez asszociáltan specifikus kromoszómaeltérést azonosítottak [3]. A $B C R-A B L 1$ génfúzió kimutatása, melynek kialakulását legtöbbször a Philadelphia-kromoszóma megjelenése kíséri, a betegség diagnózisának később alapfeltételévé vált, és a fúziós géntermék további vizsgálata a valódi forradalmat hozó tirozinkináz-gátló kezelések kulcsát jelentette [4]. A rohamosan fejlődő molekuláris genetikai technikákkal végzett átfogó tanulmányoknak köszönhetően egyre több hematológiai daganat genetikai hátterét sikerül részletesen feltérképezni, valamint ennek kapcsán olyan markereket azonosítani, melyek adott esetben segítik a diagnózis felállítását, a betegség szubklasszifikációját, a prognózis meghatározását, a leghatékonyabb terápia kiválasztását, a residualis tumortömeg nyomon követését, sőt akár célpontokként szolgálhatnak célzott kezelések kifejlesztéséhez, alkalmazásához [5-7]. Ennek következtében a legfontosabb markerek molekuláris tesztekkel való szürése mára szerves részévé vált az onkohematológiai megbetegedések mindennapi diagnosztikájának és monitorozásának.

Az elmúlt másfél évtizedben végzett expressziós vagy genomikus „array-" alapú, valamint új-generációs szekvenálási („next-generation sequencing” - NGS) vizsgálatokkal teljes exom- és genomszinten sikerült számos, a klinikai döntéshozatal szempontjából releváns genetikai eltérést azonosítani, beleértve kiegyensúlyozott, azaz DNS-kópiaszám-változással nem járó, valamint kiegyensúlyozatlan, bizonyos genomikus régiók vesztésével (deletio), nyerésével vagy sokszorozódásával (amplifikáció) járó aberrációkat. Az újonnan szerzett ismereteknek a diagnosztikai munkafolyamatba való beillesztéséhez szükség van gyors, megbízható és költséghatékony módszerekre, melyekkel az adott entitásra jellemző aberráci- ók a lehető legátfogóbban és legkevesebb humánerőforrás-ráfordítással kimutathatók.

A multiplex ligatiofüggő szondaamplifikáció (MLPA) egy olyan technika, mellyel körülbelül 50 genomikus lókusz kópiaszám-eltérései és/vagy mutációi detektálhatók egyidejúleg. A módszer 24 órán belül eredményt szolgáltat, és a protokoll minimális módosításával specifikus lókuszok DNS-metilációs mintázatai is vizsgálhatók. Az MLPA számos konstitucionális genetikai rendellenesség diagnosztikájában használható, és nemzetközi tanulmányok alapján a daganatos betegségek területén is hatékonynak bizonyult [8-10]. Széles körú alkalmazása a hazai hematológiai diagnosztikában még nem valósult meg, ezért az alábbiakban bemutatjuk az MLPA technikai hátterét, tárgyaljuk előnyeit és korlátait, valamint áttekintjük az onkohematológiai kutatásban betöltött szerepét és a módszerben rejlő potenciális diagnosztikai lehetőségeket.

\section{Az MLPA technikai háttere}

Az MLPA multiplex polimeráz-láncreakción (PCR) alapuló félkvantitatív módszer, melynek során nem magát a minta-DNS-t, hanem az annak specifikus, vizsgálandó szakaszaihoz hibridizált szondákat sokszorozunk fel. A keletkezett PCR-termékek hossz alapján történő szétválasztását és mennyiségi meghatározását fluoreszcens kapilláris elektroforézissel végezzük. Kiegyensúlyozatlan eltérések vizsgálatakor az adott genomikus szakasz betegmintában lévő kópiaszámára a keletkezett, lókuszspecifikus PCR-termékek normálkontrollokhoz viszonyított relatív mennyiségéből következtetünk [11]. Deletio esetén az adott genomikus pozícióban a normál-referenciamintához képest kevesebb PCR-termék keletkezik, nyerés-sokszorozódás esetén az elvártnál több. Az MLPA folyamatát az 1 . ábra szemlélteti.

A módszer magas specificitását az biztosítja, hogy minden egyes vizsgálandó genomikus lókuszhoz két vagy három, közvetlenül egymás mellé hibridizáló szondaoligonukleotidot kapcsolunk, melyek kizárólag tökéletes illeszkedés esetén egyesíthetők és amplifikálhatók. Ligálással való összekapcsolás hiányában amplifikációs termék nem keletkezik. A szondaoligonukleotid pároktripletek egyesítését végző ligáz-65 enzim érzékeny a minta nukleotidszekvenciájának eltérései miatt a ligatiós helyen bekövetkező tökéletlen hibridizációra, ami így lehetőséget nyújt specifikus mutációk kimutatására, a szondák csatlakozási helyének mutációs „hotspot”-ra való tervezése által. A mutációspecifikus MLPA-szondákkal korábban megfelelően felderített, specifikus nukleotidcseréket lehet kimutatni (például T>A szubsztitúció), így igazán hatékonyan akkor alkalmazhatók, ha a vizsgált entitásban gyakran jelenik meg olyan visszatérő mutáció, mely diagnosztikus vagy terápiás jelentőséggel bír.

A metilációszenzitív MLPA (MS-MLPA) a klasszikus MLPA egy olyan változata, mellyel a kópiaszám-eltéré- 
A) Denaturáció és hibridizáció

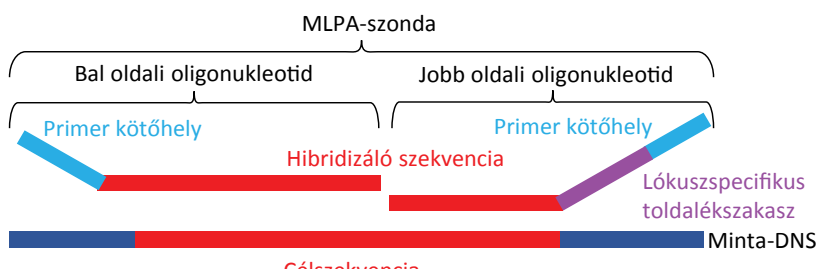

Célszekvencia

B) Ligálás

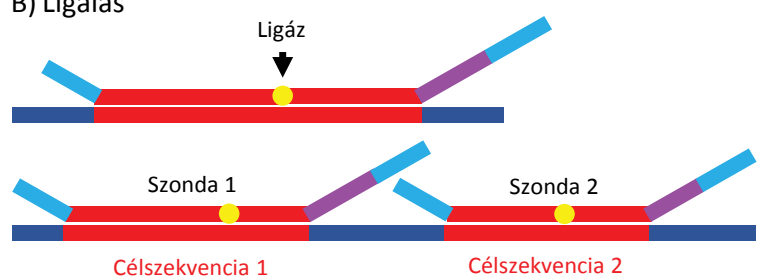

C) Amplifikáció fluoreszcensen jelölt, univerzális primer párral Amplifikált

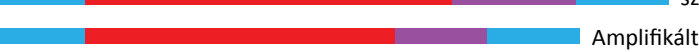

D) Fragmensszeparáció fluoreszcens kapilláris elektroforézissel

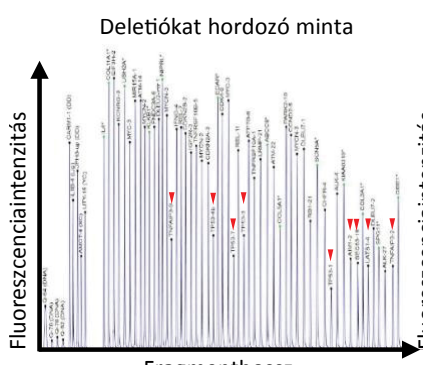

Fragmenthossz

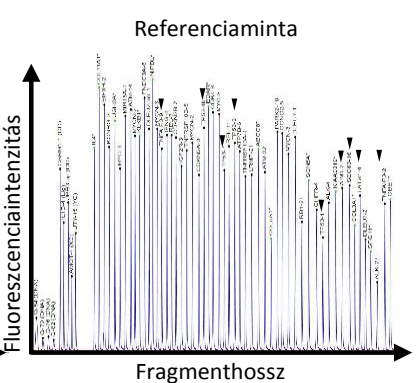

Fragmenthossz
E) Kópiaszám-meghatározás

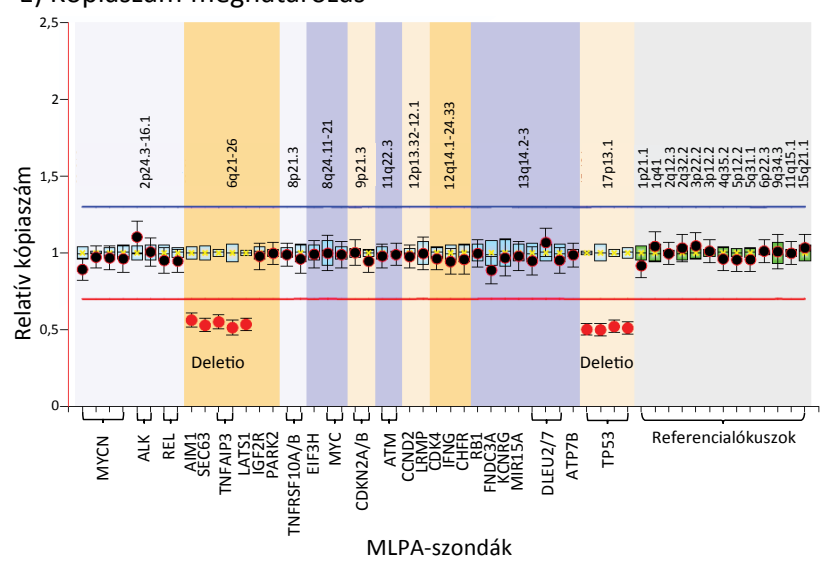

1. ábra

A multiplex ligatiofüggő szondaamplifikáció módszertani lépései. A minta-DNS, valamint a szondaoligonukleotidok denaturációját az utóbbiak specifikus célszekvenciákhoz való hibridizációja követi. A tökéletesen illeszkedő, szomszédos szondaoligonukleotidok ligálással való összekapcsolása után az adott reakciótérben lévő összes komplett szonda ugyanazon fluoreszcensen jelölt primer párral kerül felsokszorozásra. A képződött PCR-termékek eltérő hosszuk alapján, fluoreszcens kapilláris elektroforézissel azonosíthatók, az egyes lókuszokhoz tartozó termékek mennyiségéből pedig az adott genomikus pozíció relatív kópiaszáma meghatározható. Normál-referenciamintákhoz képest a termék alacsonyabb mennyisége deletióra, míg többlete nyerésre/sokszorozódásra utal sek és mutációk mellett bizonyos lókuszok DNS-metilációs státusza is kimutatható [12]. Az eljárás során a ligálást megelőzően ketté kell választani a mintát tartalmazó reakcióelegyet, majd a ligálást $\mathrm{HhaI}$ endonukleáz jelenlétében, valamint a nélkül is el kell végezni. Ha a HhaI enzim által felismert szekvencia (GCGC) nem metilált a minta-DNS-ben, az endonukleáz elhasítja a mintaszondahibridet, megakadályozva a szonda későbbi amplifikációját, míg metilált minta-DNS esetén a szonda intakt marad. Értékeléskor a HhaI által kezelt és nem kezelt minták eredményei kerülnek összehasonlításra, melyből a metilációs státusz meghatározható $[10,13]$.

Az MLPA-vizsgálat átlagolt információt nyújt arról a sejtpopulációról, amelyből a DNS-izolálás történt. Ebből következően a minta megfelelően magas tumorsejtaránya, valamint annak pontos ismerete elengedhetetlen a korrekt analízishez, illetve az eredmény helyes értelmezéséhez. Klonális monoallélikus deletio detektálásához legalább 20-30\%, biallélikus vesztés felismeréséhez 10$20 \%$ tumorsejt jelenléte szükséges. Az egyik allélt érintő mutációk már 5-10\%-os reprezentáltság esetén is kimutathatók, míg metilált genomikus pozíciók azonosításához a metilált DNS minimum 30\%-os jelenléte szükséges. A relatív kópiaszám 50\%-os csökkenése 50\%-os tisztaságnál biallélikus vesztésre utal, míg 100\%-os tisztaságú mintánál klonális monoallélikus deletio valószínüsíthető, azonban szubklonális biallélikus vesztés sem zárható ki. Hematológiai betegségek esetén gyakran áll rendelkezésre áramlási citometriai mérés, melyből a mintatisztaság megbecsülhető, a mono- és biallélikus vesztések, illetve nyerések esetén várható szignálértékek kiszámolhatók. Ha csak szöveti metszet áll rendelkezésre, digitális képanalízissel kombinált morfológiai-immunhisztokémiai térképezés segítheti a pontos tumorsejtarány meghatározását.

\section{Az MLPA előnyei és korlátai}

Az MLPA előnyei az alábbiakban foglalhatók össze: (i) DNS-alapú módszer, mely ezáltal alkalmas hosszú ideig archivált anyagok vizsgálatára is; (ii) nem igényel intakt sejteket/sejtmagokat kiindulási mintaként; (iii) 20-150 ng DNS elegendő a reakció elvégzéséhez; (iv) mivel a szondák célponthoz hibridizáló szakasza meglehetôsen rövid (55-80 bp közötti), a módszerrel egyedi exonok is vizsgálhatók, továbbá (v) a reakció fragmentált DNSmintán is elvégezhető, lehetővé téve formalinfixált, paraffinba ágyazott anyagok vizsgálatát, mely a patológiai diagnosztikában kiemelt jelentőségű [14]; (vi) a módszer 24 órán belül eredményt szolgáltat, akár 96 lyukú plate-ekben is kivitelezheto, és viszonylag könnyü automatizálni; (vii) költséghatékony, amit az is segít, hogy egy PCR-készüléken, illetve kapilláriselektroforézis-készüléken kívül nem igényel speciális müszerezettséget; (viii) az eredmények értékelése ingyenesen elérhető szoftverrel elvégezhető, mely segíti a dokumentációt is; (ix) kópiaszám-eltérések, metiláltsági státuszok, vala- 
mint mutációk egyidejűleg vizsgálhatók vele; végül, $(x)$ az elérhető szondamixek összetétele rugalmasan változtatható, amennyiben új, klinikailag releváns aberrációk kerülnek azonosításra.

A fentebb említett előnyök mellett az MLPA onkohematológiai diagnosztikában és kutatásban való alkalmazásakor korlátokkal is kell számolni, úgymint (i) a módszerrel nem lehet kópiaszám-eltéréssel nem járó citogenetikai aberrációkat kimutatni, mint például kiegyensúlyozott transzlokációkat és inverziókat, ezenkívül komplex eltérések (például chromothrypsis) vizsgálata is túl nagy kihívást jelenthet; (ii) a technika relatív kópiaszám-eltéréseket mutat ki, így poliploidia vagy haploidia félrevezetheti az eredmények értelmezését; (iii) a klonális, egyetlen kópiaeltérést okozó aberrációknak a szubklonális, többszörös kópiaszám-eltéréshez vezető laesióktól való elkülönítése nehézségekbe ütközhet; (iv) az MLPA érzékeny az alacsony tumorsejtarányra, illetve a 20 ng-nál alacsonyabb kiindulási minta használatára; (v) egyedi sejtek nem vizsgálhatók, ami azonban hasznos lehetne a számos betegségben bizonyítottan jelen lévő, komplex szubklonális szerkezet felderítéséhez; (vi) egyes szondáknál mutatkozó, relatív kópiaszám-eltérésre utaló szignálok hátterében mutáció okozta álpozitivitás is állhat; (vii) az MLPA-val nem lehet kópiaszám-eltéréseket teljes genomszinten felderíteni, alkalmazása korlátozódik a szondák által lefedett, körülbelül 50 genomikus lókuszra; (viii) ismeretlen mutációk kimutatása nem lehetséges, valamint a szondák által lefedett pozíciókban is csak specifikus nukleotidcserék detektálhatók; $(i x)$ közeli genomikus pozíciókban megjelenő mutációk kimutatása technikailag megoldhatatlan/alacsony hatékonyságú lehet a szondaoligonukleotidok egymással való szükségszerü hibridizációs versengése miatt; $(x)$ metiláció kimutatása csak olyan lókuszok esetében lehetséges, melyek a HhaI restrikciós enzim felismerési helyeinél jelentkeznek.

\section{Az MLPA alkalmazása leukaemiák és lymphomák vizsgálatához}

A nemzetközi irodalomban számos közlemény számol be az MLPA onkohematológiai kórképekben való alkalmazásáról, bizonyítva a technika alkalmasságát malignus vérképző rendszeri betegségek genetikai vizsgálatára. Az alábbiakban néhány példán keresztül bemutatjuk a módszerben rejlő, máig publikált lehetőségeket.

Az egyik legkorábbi, 2006-ban megjelent onkohematológiai MLPA-közlemény Buijs és mtsai nevéhez füződik, akik a leggyakoribb felnőttkori leukaemiatípusban, krónikus lymphocytás leukaemiában (CLL) szenvedő 54 beteg mintáját vizsgálva azonosítottak ismert visszatérő kópiaszám-eltéréseket, valamint további, fluoreszcencia in situ hibridizációval (FISH) nem detektált deletiókat, illetve számbeli kromoszómaeltéréseket [15]. Ezt követően számos munkacsoport alkalmazta a módszert ugyancsak a CLL vizsgálatához, leginkább a prognoszti- kai jelentőséggel bíró TP53-, ATM- és 13q-deletiók, valamint a 12-es triszómia kimutatására [16-19]. Az MLPA költséghatékonyságát, magas áteresztőképességét és mérsékelt munkaerő-ráfordítási igényét több esetben is megerősítették [16,20]. Az összehasonlító módszertani vizsgálatok nagymértékü egyezést fedtek fel az MLPA, valamint a FISH- és „microarray-” alapú technikákkal nyert eredmények között. A néhány, összhangban nem álló adat hátterében a malignus klón alacsony reprezentáltsága, illetve a különféle módszerek által nyújtott eltérő genomikus feloldás és lefedettség állt [16, 17, 20, 21]. Emellett egy Véronèse és mtsai által közölt tanulmány felhívta a figyelmet a pontmutációk által okozott álpozitív, látszólag kópiaszámvesztésre utaló MLPAeredményekre, ezáltal a validálás fontosságára. Megjegyzendő azonban, hogy esetükben a probléma a TP53-gén vizsgálata kapcsán mutatkozott, melynek deletiója és gyakran patogén mutációja egyaránt prognosztikailag kedvezőtlen eltérésnek tekinthető CLL-ben [21, 22]. A TP53-, illetve az ATM-gén státuszának felmérése az elmúlt években különösen relevánssá vált CLL-es betegekben, mivel ezeknek a géneknek a hibái szorosan összefüggenek a kemorezisztenciával, aberrációik kimutatása esetén pedig célzott terápia is elérhető $[23,24]$. A TP53és az $A T M$-, valamint a velük funkcionális kapcsolatban lévő, DNS-károsodásra adott válaszban szerepet játszó gének RNS-alapú vizsgálatához Eldering és munkacsoportja reverz transzkripciót követően használt MLPA-t $[25,26]$. A módszer ezen alternatív alkalmazásával el tudtak különíteni funkcionális p53-defektust hordozó betegeket ATM-defektussal bíróktól, valamint további, az előző kettőre nézve normális, de DNS-károsodásra adott válasz szempontjából más okból funkcionális szinten abnormalitást mutató betegeket is azonosítani tudtak.

Az MLPA-hoz köthető legintenzívebb publikációs aktivitás az akut lymphoblastos leukaemia (ALL) vizsgálata kapcsán tapasztalható. Először 2010-ben, Schwab és mtsai alkalmazták a módszert prekurzor B-sejtes ALLben szenvedő betegek mintáin, melynek során a betegségben visszatérően megjelenő, a B-sejt-fejlődésben, lymphoid differenciálódásban, sejtciklus-szabályozásban szerepet játszó, prognosztikai és terápiás relevanciával bíró gének kópiaszám-eltéréseit vizsgálták [27]. MLPAval többek között azonosítottak FISH-sel nem detektálható, kis kiterjedésű deletiókat is, melyeket kvantitatív PCR-rel sikeresen validáltak. A módszer hatékonyságát demonstráló tanulmányukban felhívták a figyelmet ugyanakkor arra is, hogy haploid, illetve tetraploid esetekben az MLPA-profil nem feltétlenül mutat abnormális mintázatot, amennyiben a mintában relatív kópiaszám-eltérés nem mutatkozik. Az MLPA hozzáadott értékét ugyanakkor egyértelmúen jelzi, hogy ezt követően több száz, esetenként ezer feletti beteget is felölelő klinikai vizsgálatok keretében alkalmazták sikerrel a technikát. A tanulmányok nagy részében az IKZFI-, $P A X 5$-, ETV6-, RB1-, BTG1-, EBF1-, CDKN2A/B, RUNX1-, 
$E R G$ - és a PARl-régió génjeinek eltéréseit vizsgálták prekurzor B-sejtes ALL-ben. Ezek közül is kiemelkedik az IKZFI (Ikaros)-gén deletiójának, illetve a 2l-es kromoszóma intrakromoszomális amplifikációja (iAMP21) következtében felsokszorozódó RUNX1-és ERG-gén eltéréseinek intenzív vizsgálata. $\mathrm{Az} I K Z F I$-deletio független prognosztikai marker, kedvezőtlen betegséglefolyással társul, gyakran fordul elő a $B C R-A B L 1$-pozitív, illetve a génfúziót nem hordozó, de hasonló génexpreszsziós mintázatot mutató $B C R-A B L 1$-szerü szubtípusokban $[28,29]$. Az iAMP21 a gyermekkori B-ALL-esetek 2\%-ában megjelenő aberráció, mely eltérést hordozó betegek a standard kezelésre rosszul reagálnak, a terápia intenzitásának emelésével azonban kedvezőbb válasz érhető el [30].

Az MLPA nem sejtalapú módszer, ezáltal az ALL néhány szubtípusára kifejezetten jellemző komplex szubklonális szerkezet feltérképezésére nem tûnik optimális eszköznek. Ugyanakkor diagnózis és relapsus idején vett mintákat összehasonlítva, a deletio által érintett lókuszok kiterjedésének több szondával való vizsgálata lehetővé teheti a két eltérő időpontban domináló malignus sejtpopuláció klonális viszonyának felderítését, ezáltal a szubklonális evolúciós folyamatokba való informatív betekintést. Alpár és mtsai az IKZFI-, míg Waanders és mtsai a BTGl-gént érintő abnormalitásokat vizsgálva mutattak ki olyan deletiós mintázatokat, melyek a relapsuskor megjelenő szubklónnak a diagnosztikus mintában domináns populációtól való független fejlődésére utaltak [31, 32].

Kópiaszám-eltérések mellett Braun és mtsai a $C D K N 2 A$ - és a $C D K N 2 B$-gén promóter régióiban elhelyezkedő $\mathrm{CpG-pozíciók} \mathrm{metiláltsági} \mathrm{státuszát} \mathrm{is} \mathrm{vizsgál-}$ ták MS-MLPA-val, gyermekkori prekurzor B-sejtes ALL-ben szenvedő betegekben [33]. Az eljárás lehetővé tette a $C D K N 2 A / B$ gének inaktivációjához vezető genetikai és epigenetikai változások egyidejű felderítését. Eredményeik alapján a $C D K N 2 A$-gén biallélikus deletiója kedvezőtlen terápiás válasszal és megnövekedett relapsuskockázattal társul, ugyanakkor tanulmányukban az eltérő inaktivációs módok (deletio és metiláció) együttes megjelenése nem volt jelentős hatással a betegek prognózisára.

Rohde és mtsai prognosztikailag releváns, heterozigótaság vesztéséhez vezető 6q-kromoszóma-kar-deletiót vizsgáltak MLPA-val prekurzor T-sejtes ALL-ben, illetve lymphoblastos lymphomában szenvedő betegekben. Konvencionális mikroszatellita vizsgálattal összehasonlítva, az MLPA megfelelő mintamennyiség és -minőség mellett költséghatékonyabbnak, valamint kevésbé időigényesnek bizonyult, továbbá csíravonalkontroll nélkül szolgáltatott informatív eredményt [34]. RichterPechanska és mtsai prekurzor T-sejtes ALL-ben szenvedő betegek diagnózis és relapsus idején vett mintáit vizsgálták, és a célzott NGS-sel detektált kópiaszám-eltéréseket 182 beteg esetében validálták MLPA-val, 99\%-os egyezést találva a két módszer között olyan eltérések alapján, melyek kimutatására elvileg mindkét technika alkalmas volt [35]. Kunz és mtsai ugyanebben az entitásban vizsgálták a relapsushoz vezető klonális evolúció hátterét. A CDKN2A/B, LEF1-, PTEN-, PTPN2-, SUZ12- és CASP8AP2-gének deletióinak, valamint a $M Y B$-gén amplifikációjának megjelenése alapján azonosítottak mindkét időpontban megjelenő aberrációkat, valamint olyanokat is, melyek csak diagnózis vagy relapsus idején mutatkoztak az egyes betegekben [36].

A szubkromoszomális kópiaszám-eltérésekre fókuszáló tanulmányok mellett aneuploidiák/aneuszómiák MLPA-val való kimutatásának lehetőségét is demonstrálták akut leukaemiás esetekben, centromerközeli vagy szubtelomerikus kromoszómarégiókhoz hibridizáló MLPA-szondákat használva [37, 38]. DNS-index-meghatározással együtt alkalmazva, az MLPA hatékony kiegészítő módszernek bizonyult, különösen pszeudodiploid esetekben, valamint amikor néhány, főleg kisméretű kromoszóma nyerése vagy vesztése állt az aneuploiditás hátterében. Ezek a Reyes-Núñez és mtsai által közölt eredmények összhangban állnak korábbi hazai tanulmányokkal, melyek szintén felhívták a figyelmet az aneuploidia hátterében álló specifikus aneuszómiák felderítésének fontosságára [39, 40].

Érett B-sejtes lymphomákat tekintve, Delfau-Larue és mtsai köpenysejtes lymphomában (MCL) vizsgáltak 13q14-, 9p21-, 11q23-, 17p13- és 12q14-deletiókat, valamint $M Y C$-gén-amplifikációt MLPA-val annak érdekében, hogy az aberrációk prognosztikus jelentőségét felfedjék immunkemoterápia, magas dózisú citarabinkezelés, illetve autológ őssejt-transzplantáció alkalmazása mellett, klinikai tanulmány keretében. Eredményeik alapján a $C D K N 2 A$ - és a TP53-gén deletiói önálló, Ki67-indextől független, kedvezőtlen prognózisssal társuló markereknek tekinthetők [4l].

Plazmasejtes myelomában Alpár és mtsai vizsgáltak először MLPA-val prognosztikai jelentőséggel bíró kiegyensúlyozatlan aberrációkat [42]. A módszer a betegek 65\%-ában azonosított olyan eltéréseket, melyeket a standard FISH-tesztek nem mutattak ki. Az MLPA azonban nem képes kiegyensúlyozott genetikai abnormalitásokat detektálni, ezért FISH-sel együtt való alkalmazása ebben az esetben kifejezetten indokolt, hiszen a myeloma biológiai osztályozásában az IGH-gén transzlokációinak kiemelt szerepük van. Az MLPA hatékonyságát myeloma vizsgálatában később más munkacsoportok is megerösítették [43].

Havranek és mtsai több mint 500, non-Hodgkinlymphomában szenvedő beteg mintájában vizsgáltak csíravonal-eredetü CHEK2-gén-deletiót MLPA-val. A diffúz nagy B-sejtes lymphomát, follicularis lymphomát, MCL-t, kis lymphocytás lymphomát és mucosaasszociált lymphoid szövet tumorját is reprezentáló betegcsoportban kétféle kereteltolódásos mutációt okozó és korai transzlációs terminációhoz vezető aberrációt azonosítottak [44]. 
Blastos krízisen áteső, CML-ben szenvedő betegek mintáit MLPA-val vizsgálva Alpár és mtsai a betegség krónikus fázisában nem mutattak ki kópiaszám-eltérést, míg egy kivétellel az összes blastos krízis idején nyert mintában azonosítottak aberrációkat [31]. Ezzel összhangban, van der Sligte és mtsai gyermekkori CML-es betegeket vizsgálva nem mutattak ki kópiaszám-eltéréseket 77 krónikus fázisú betegben, míg egy kivétellel minden olyan betegben találtak eltérést, akiket akcelerált fázisban vagy lymphoblastos krízisben diagnosztizáltak, esetleg krónikus fázisból progrediáltak [45].

Donahue és mtsai myelodisplasiás szindrómában, illetve akut myeloid leukaemiában szenvedő betegek vizsgálatához tesztelték az MLPA használhatóságát egy -5 / del5q-, -7/del7q-, +8-, del17p-, del20q- és 21q-abnormalitásokat egyidejúleg kimutatni képes szondakeverékkel, 89-93\%-os konkordanciát elérve a módszer eredményeinek FISH-adatokkal való összevetése során. A szerzők a FISH-analízishez képest jelentősen csökkent mintapreparálási és -analizálási időigényről, valamint a költségek legalább hétszeres csökkenéséről számoltak be [46].

Végül, egy hematológiai betegségek átfogó vizsgálatához kifejlesztett, 19 kromoszómakart lefedő MLPAszonda-keverékkel Konialis és mtsai több mint 300, diagnosztikai vizsgálatra küldött csontvelőmintát analizáltak, az eredményeket kariotipizálási és FISH-adatokkal összehasonlítva [47]. A mind lymphoid, mind myeloid malignitásokat magában foglaló betegpopuláció 8\%ában azonosítottak olyan klinikailag releváns aberrációkat, melyeket a hagyományosabb citogenetikai módszerek nem fedtek fel. Az MLPA olyan esetekben is segítséget nyújtott, amikor a metafázisok hiánya miatt a kariotipizálás nem volt kivitelezhető.

Összességében, a teljesség igénye nélkül fent bemutatott példák egyértelműen jelzik, hogy az MLPA sokoldalúan hasznosítható technika onkohematológiai betegségek vizsgálatához, beleértve a diagnosztikai munkafolyamatban való alkalmazást is. A genetikai eltérések különféle hematológiai betegségekben való kimutatását a 2 . ábra szemlélteti.

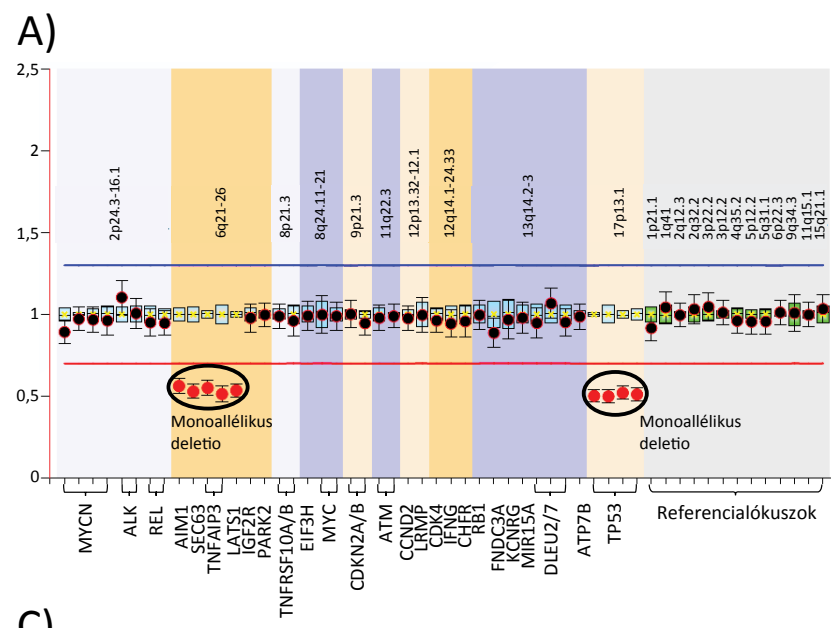

B)

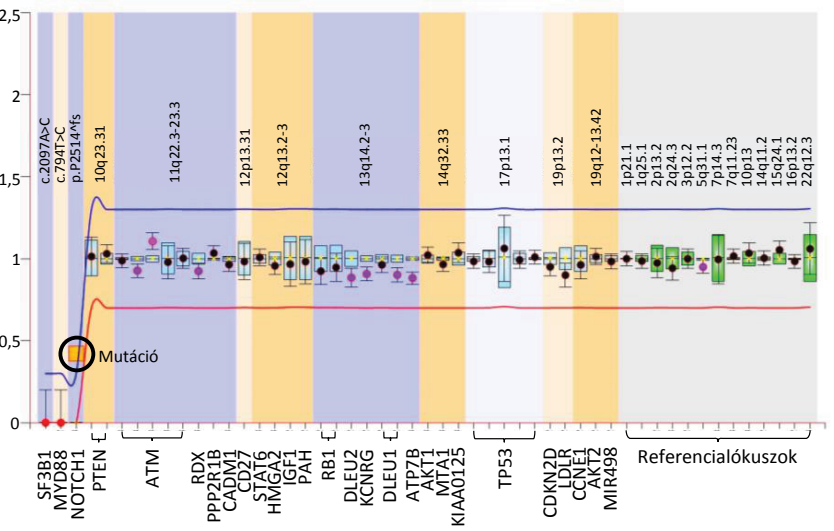

C)

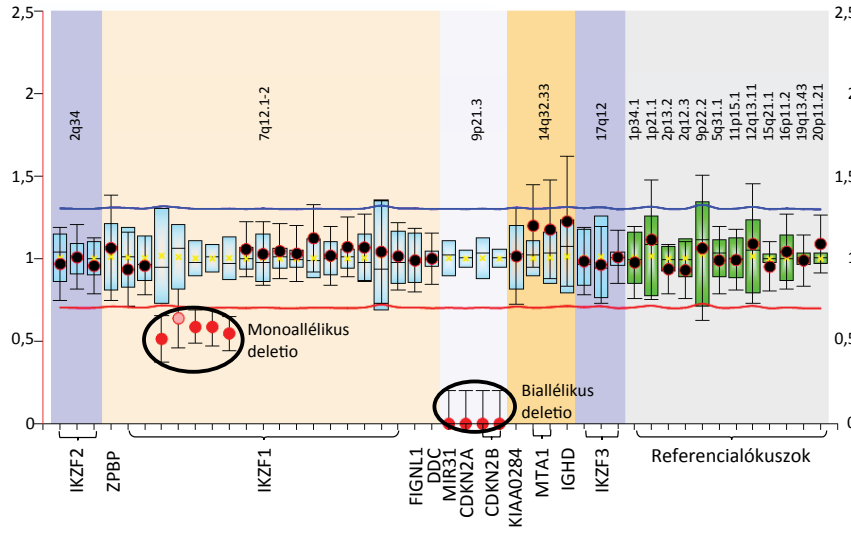

D)

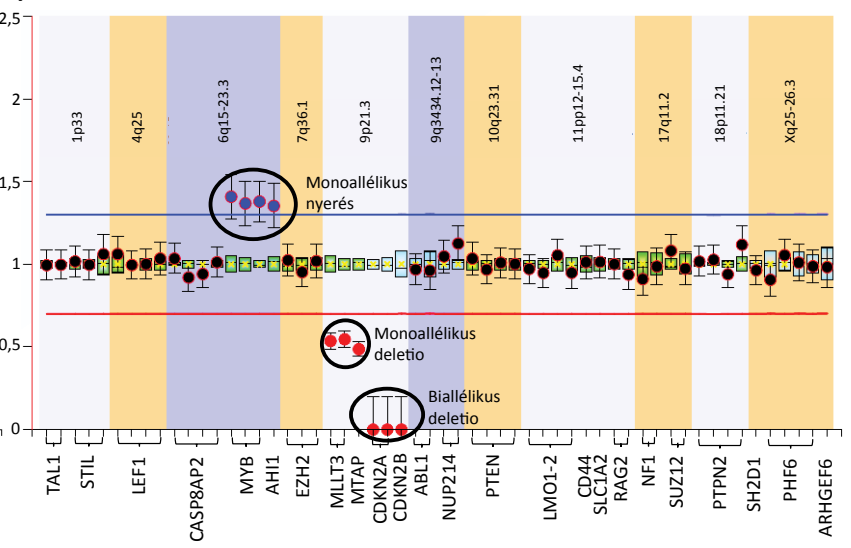

2. ábra

DNS-kópiaszám-eltérések és mutáció kimutatása multiplex ligatiofüggő szondaamplifikációval. A) Monoallélikus 6q- és 17p-deletiók CLL-ben szenvedő beteg perifériás vérmintájában (SALSA P037 szondakeverék). B) NOTCHI p.2514*fs kereteltolódásos mutáció kimutatása CLL-ben szenvedő beteg perifériás vérmintájában (SALSA P038 szondakeverék). A megfelelő szonda ligálása és amplifikációja csak a CLL-es betegek 5\%-ában mutatkozó és kedvezótlen prognózissal társuló mutáció jelenlétében megy végbe. C) Monoallélikus IKZFI-deletio, illetve biallélikus 9p-deletio gyermekkori prekurzor B-sejtes ALL-ben szenvedő beteg diagnosztikus csontvelőmintájában (SALSA P202 szondakeverék). D) MYB-gén-nyerés, valamint monoés biallélikus 9p-deletio gyermekkori prekurzor T-sejtes ALL-ben szenvedő beteg diagnosztikus csontvelőmintájában (SALSA P383 szondakeverék). A bemutatott MLPA-vizsgálatok a Semmelweis Egyetem I. Sz. Patológiai és Kísérleti Rákkutató Intézetének Molekuláris Onkohematológiai Laboratóriumában készültek 


\section{Az MLPA lehetséges helye a patológiai diagnosztikában}

A hazai diagnosztikában jelenleg a kariotipizálás és a FISH a legelterjedtebb módszerek hematológiai betegségek citogenetikai vizsgálatához, míg pontmutációk, valamint kisméretü inszerciók, deletiók és inverziók kimutatásához a Sanger-szekvenálás használatos a leginkább.

Kariotipizálással a teljes kromoszómakészlet vizsgálható, lókusztól és preparálási protokolltól függően 3-10 megabázisfeloldással. A módszer időigényes, és magasan képzett technikusokat kíván, teljes automatizációja a kromoszómák morfológiai variabilitása miatt nem valósítható meg. Az eljárás lehetővé tesz egysejt-alapú vizsgálatot, az alkalmanként 20, legfeljebb 30 osztódás analízise azonban szubklonális aberrációk kimutatását erősen korlátozza. Kiindulási mintaként a technika osztódó sejteket kíván, az alkalmazott in vitro tenyésztés pedig klonális szelekciót idézhet elő, aminek következtében a vizsgált osztódásokban a malignus klón alulreprezentálttá válhat. További nehézség, hogy néhány entitásnál, például az ALL egyes szubtípusaiban az abnormális osztódások minősége, kromoszómáik felismerhetősége lényegesen rosszabb a mintában megjelenő normálosztódásokéhoz képest, ami a vizsgálatot elfogulttá teheti.

A FISH nem igényel élő sejtet, a reakció bármely patológiai mintatípuson elvégezhető, és a kariotipizálással ellentétben legkésőbb 24 órán belül eredményt szolgáltat. A vizsgálat a leggyakrabban 200 interfázisban lévő sejt analízisét foglalja magában, mely a kromoszómapreparátumok értékeléséhez képest nagyobb statisztikai megbízhatóságot nyújt [48]. Emellett a módszer feloldása is magasabb, a diagnosztikában használatos szondákkal tipikusan 1-2 megabázis és 100 kilobázis közötti tartomány érhető el, míg az ennél kisebb kiterjedésü (40-50 kilobázis) eltérések vizsgálatához kutatási céllal létrehozott szondák használatosak [49]. A FISH célzott vizsgálatot tesz lehetővé, tipikusan két-három, ritkábban négy lókusz egyidejű analízisével, mely a fluoreszcens jelölőanyagok részben átfedő gerjesztési és emissziós spektrumainak, valamint a detektálható fény korlátozott terjedelmű hullámhossztartományának köszönhető. Bár a FISH a kariotipizáláshoz képest kiterjedtebb mértékben automatizálható, mikromorfológiai módszerről lévén szó, a jelek mintázatának helyes értelmezése és az eredmények precíz értékelése szintén igényel előképzettséget, valamint bizonyos mértékü manuális interakciót.

Mutációk és kisméretű strukturális aberrációk kimutatásához a Sanger-szekvenálás a legelterjedtebb technika, mely bázispárfeloldással képes a mintában legalább 20\%ban reprezentált genetikai eltéréseket vizsgálni. A módszer a nukleinsavmintáról átlagolt, nem egysejt-szintü információt nyújt, körülbelül 500 nukleotid terjedelemben. Egymástól távolabb elhelyezkedő genomikus régiók vizsgálatához több reakció elvégzése szükséges, és nagy kiterjedésú kópiaszám-eltérések kimutatása az eljárással nem lehetséges.

Mindezeket figyelembe véve az MLPA hatékony kiegészítő technikának tűnik (i) microdeletiók kimutatásához, akár egyediexon-szinten, ami kariotipizálással és FISH-analízissel nem érhető el; (ii) klinikailag releváns, gyakran megjelenő mutációk Sanger-szekvenálásnál érzékenyebb szüréséhez; (iii) olyan esetekben, amikor több, mint két-három genomikus lókusz kópiaszám-eltérésének együttes, költséghatékony vizsgálata indokolt, valamint (iv) molekuláris patológiai laboratóriumokban, ahol mikroszkópos vagy „array-" alapú citogenetikai vizsgálatokra müszer vagy képzett személyzet hiányában nem nyílik lehetőség. Az MLPA-reakció, mellyel kópiaszám-változások, mutációk, illetve metilációs mintázatok egyidejűleg vizsgálhatók, bármely szövettípuson elvégezhető, és alkalmazását nem akadályozza a formalinos fixálás és paraffinba történő ágyazás sem, mely patológiai minták vizsgálatánál kiemelt fontosságú. A szondakeverék rugalmas módosíthatóságából adódóan újabb markerek vizsgálata könnyedén megvalósítható, aminek az NGS miatt bekövetkezett genomikus forradalom idején különösen nagy jelentősége van. Emellett a módszert könnyü automatizálni, az értékelés menete néhány óra alatt elsajátítható, a reakciók 96-lyukú plate-eken való kivitelezése pedig a legnagyobb hazai laboratóriumok számára is elegendő áteresztőképességet biztosít, kevesebb mint 24 órás átfordulási idővel.

\section{Az MLPA jövője}

Az onkohematológiai betegségek genetikai kutatása és diagnosztikája több mint 50 évvel a Philadelphia-kromoszóma felfedezése után, még manapság is rendkívül dinamikusan fejlődő terület. Ez jelentős mértékben köszönhető az utóbbi 10-15 évben bekövetkezett technológiai fejlődésnek, mely az orvosbiológiai minták genomikai tanulmányozását mind mélység, mind átfogó- és áteresztőképesség tekintetében magasabb szintre emelte. Az NGS korában egyre gyakrabban merül fel kérdésként a klasszikus és molekuláris citogenetikai technikák létjogosultsága, illetve alkalmazásuk várható élettartama. Az elkövetkezendő években az NGS jelentős térnyerése várható, köszönhetően sokoldalú alkalmazhatóságának, egységnyi adatmennyiségre vonatkoztatva fokozatosan csökkenő árának, valamint az adatok értékelését egyre könnyebbé tevő grafikus szoftvereknek.

Jelenleg azonban úgy tûnik, hogy a hazai diagnosztikai munkafolyamatnak még sokáig szüksége lesz olyan módszerekre, melyek gyorsaságuk és megbízhatóságuk mellett költséghatékonyak is. Valószínúleg részben ez a szempont vezetett ahhoz is, hogy az „array-” alapú vizsgálatok - kutatási célú alkalmazásaik ellenére - végül nem váltak rutinszerúen használatos eszközzé a hazai onkohematológiai diagnosztikában. Emellett ismereteink szerint az egyes hematológiai entitások többségére viszonylag limitált számú visszatérő genetikai eltérés jel- 


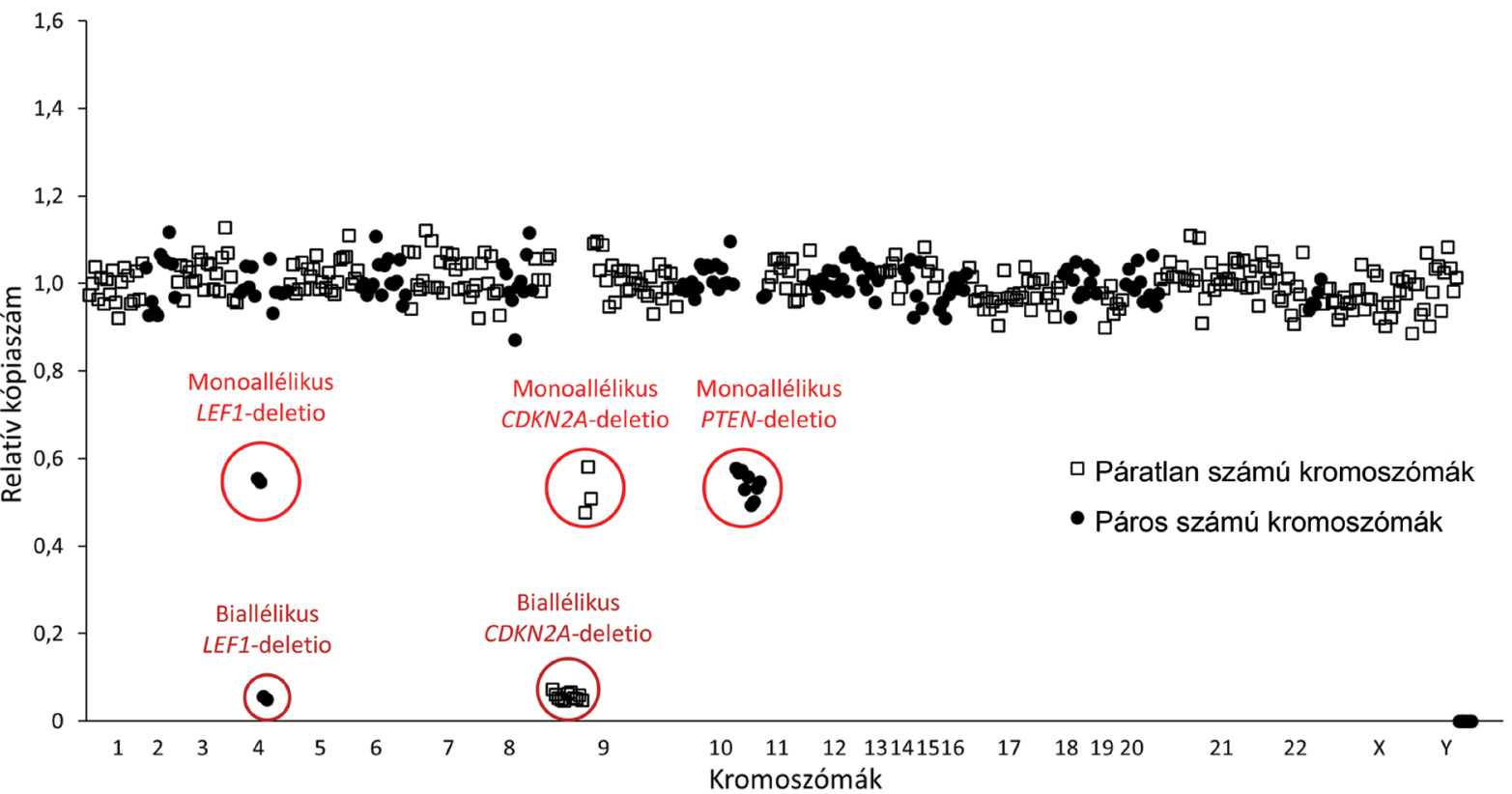

3. ábra

DNS-kópiaszám-eltérések kimutatása digitális multiplex ligatiofüggő szondaamplifikációval. Prekurzor T-sejtes ALL-ben szenvedő beteg diagnosztikus csontvelőmintájában a több mint 600 szondát tartalmazó D007 szondakeverék mono- és biallélikus deletiót detektál a $L E F 1$ - és a $C D K N 2 A$ génben, valamint monoallélikus deletiót a PTEN-génben. A bemutatott digitális-MLPA-vizsgálat a Semmelweis Egyetem I. Sz. Patológiai és Kísérleti Rákkutató Intézetének Molekuláris Onkohematológiai Laboratóriumában készült

lemző, aminek alapján a célzott vizsgálómódszerek használata kézenfekvőnek tünik. Az MLPA ebben a környezetben hatékonyan alkalmazható eljárás, a kereskedelmi forgalomban számos betegséghez érhető el specifikus szondakeverék, akár igény szerinti módosításokkal is (www.mlpa.com). Mi több, egy közelmúltbeli tanulmány arra utal, hogy a módszer kifejlesztői (MRC-Holland, Amszterdam) nem versenyezni, sokkal inkább élni kívánnak az NGS nyújtotta új lehetőségekkel. Az MLPA NGS-sel való ötvözéseként született meg a közelmúltban a digitális MLPA, melynek az MLPA-hoz viszonyított előnye az egyidejúleg vizsgálható lókuszok számának jelentős, körülbelül tízszeres emelkedése, ami a jövőben még tovább bővíthető, akár 1000 genomikus lókusz együttes vizsgálatát lehetővé téve [50] (3. ábra). Ennek technikai hátterét a szondákat reprezentáló PCRtermékek relatív mennyiségének Illumina szekvenálón való meghatározása biztosítja, mely a fragmenthosszanalízishez képest jóval hatékonyabb termékelválasztást/ szondaazonosítást tesz lehetővé, a PCR-termékek genomikus szekvenciájának pontos meghatározása által. Bár irodalmi adatok alapján a digitális MLPA-t máig csak ALL analíziséhez használták, új szondakeverékek megjelenése várható további haemopoeticus betegségek, például plazmasejtes myeloma vizsgálatához is.

\section{Következtetés}

Az MLPA egy megbízható molekuláris genetikai módszer DNS-kópiaszám-eltérések, specifikus mutációk, illetve bizonyos genomikus pozíciókban metiláció célzott detektálásához. A diagnosztikában jól alkalmazható eljárásról van szó, melynek széles körü hazai alkalmazása előtt nem állnak komoly technikai nehézségek. A digitális MLPA ugyanakkor új, jelenleg még tesztelési fázisban lévő kutatási módszer, melynek a mindennapi diagnosztikában való elterjedésére várhatóan jelentős hatással lesz leendő, a nem elhanyagolható szekvenálási költséget is magában foglaló ára.

Anyagi támogatás: A közlemény megírásához kapcsolódó munkát a Nemzeti Kutatási, Fejlesztési és Innovációs Hivatal - NKFIH, K_16 K119950 és NVKP_16-12016-0004 - pályázatai, az Új Nemzeti Kiválósági Program ÚNKP-17-4-III-SE-9 pályázata, valamint a Magyar Tudományos Akadémia Lendület Programjának LP95021 pályázata támogatta. Az ábrákon bemutatott adatokhoz a szondakeverékeket az MRC-Holland bocsátotta a szerzők rendelkezésére.

Szerzői munkamegosztás: A. D.: A közlemény szerkezetének megtervezése. K. R., K. Sz., G. A., Sz. K., B. Cs., A. D.: A kézirat elkészítése. A cikk végleges változatát valamennyi szerző elolvasta és jóváhagyta.

Érdekeltségek: A szerzőknek a közleményhez kapcsolódó közvetlen érdekeltségeik nincsenek.

\section{Irodalom}

[1] Greaves M. Leukaemia 'firsts' in cancer research and treatment. Nat Rev Cancer 2016; 16: 163-172.

[2] Alexandrov LB, Nik-Zainal S, Wedge DC, et al. Signatures of mutational processes in human cancer. Nature 2013; 500: 415421 .

[3] Nowell PC, Hungerford DA. A minute chromosome in human chronic granulocytic leukemia. Science 1960; 132: 1497. 
[4] Druker BJ, Tamura S, Buchdunger E, et al. Effects of a selective inhibitor of the $\mathrm{Abl}$ tyrosine kinase on the growth of $\mathrm{Bcr}-\mathrm{Abl}$ positive cells. Nat Med. 1996; 2: 561-566.

[5] Swerdlow SH, Campo E, Pileri SA, et al. The 2016 revision of the World Health Organization classification of lymphoid neoplasms. Blood 2016; 127: 2375-2390.

[6] Arber DA, Orazi A, Hasserjian R, et al. The 2016 revision to the World Health Organization classification of myeloid neoplasms and acute leukemia. Blood 2016; 127: 2391-2405.

[7] Taylor J, Xiao W, Abdel-Wahab O. Diagnosis and classification of hematologic malignancies on the basis of genetics. Blood 2017; 130: $410-423$.

[8] Dávid A, Butz H, Halász Z, et al. The prevalence of SHOX gene deletion in children with idiopathic short stature. A multicentric study. [A SHOX géndeletio előfordulása idiopathiás alacsonynövésben. Multicentrikus tanulmány.] Orv Hetil. 2017; 158: 1351-1356. [Hungarian]

[9] Kövesdi E, Bene J, Nagy N, et al. Importance of gross deletions in the diagnosis of tuberous sclerosis complex: the first Hungarian cases. [A nagyobb méretü géndeletiók jelentősége a sclerosis tuberosa diagnosztikájában: az első magyar esetek bemutatása.] Orv Hetil. 2017; 158: 1188-1194. [Hungarian]

[10] Homig-Holzel C, Savola S. Multiplex ligation-dependent probe amplification (MLPA) in tumor diagnostics and prognostics. Diagn Mol Pathol. 2012; 21: 189-206.

[11] Schouten JP, McElgunn CJ, Waaijer R, et al. Relative quantification of 40 nucleic acid sequences by multiplex ligation-dependent probe amplification. Nucleic Acids Res. 2002; 30: e57.

[12] Nygren AO, Ameziane N, Duarte HMB, et al. Methylation-Specific MLPA (MS-MLPA): simultaneous detection of CpG methylation and copy number changes of up to 40 sequences. $\mathrm{Nu}$ cleic Acids Res. 2005; 33: el28.

[13] Moelans CB, Atanesyan L, Savola SP, et al. Methylation-Specific Multiplex Ligation-Dependent Probe Amplification (MSMLPA). Methods Mol Biol. 2018; 1708: 537-549.

[14] Atanesyan L, Steenkamer MJ, Horstman A, et al. Optimal fixation conditions and DNA extraction methods for MLPA analysis on FFPE tissue-derived DNA. Am J Clin Pathol. 2017; 147: $60-68$.

[15] Buijs A, Krijtenburg PJ, Meijer E. Detection of risk-identifying chromosomal abnormalities and genomic profiling by multiplex ligation-dependent probe amplification in chronic lymphocytic leukemia. Haematologica 2006; 91: 1434-1435.

[16] Coll-Mulet L, Santidrián AF, Cosialls AM, et al. Multiplex ligation-dependent probe amplification for detection of genomic alterations in chronic lymphocytic leukaemia. $\mathrm{Br} \mathrm{J}$ Haematol. 2008; 142: 793-801.

[17] Stevens-Kroef M, Simons A, Gorissen H, et al. Identification of chromosomal abnormalities relevant to prognosis in chronic lymphocytic leukemia using multiplex ligation-dependent probe amplification. Cancer Genet Cytogenet. 2009; 195: 97-104.

[18] Groenen PJ, Raymakers R, Rombout PD, et al. High prevalence of adverse prognostic genetic aberrations and unmutated IGHV genes in small lymphocytic lymphoma as compared to chronic lymphocytic leukemia. J Hematopathol. 2011; 4: 189-197.

[19] Fabris S, Scarciolla O, Morabito F, et al. Multiplex ligation-dependent probe amplification and fluorescence in situ hybridization to detect chromosomal abnormalities in chronic lymphocytic leukemia: a comparative study. Genes Chromosomes Cancer 2011; 50: 726-734

[20] Al Zaabi EA, Fernandez LA, Sadek IA, et al. Multiplex ligationdependent probe amplification versus multiprobe fluorescence in situ hybridization to detect genomic aberrations in chronic lymphocytic leukemia: A tertiary center experience. J Mol Diagn. 2010; 12: 197-203.

[21] Véronèse L, Tournilhac $O$, Combes $P$, et al. Contribution of MLPA to routine diagnostic testing of recurrent genomic aberrations in chronic lymphocytic leukemia. Cancer Genet. 2013; 206: 19-25.
[22] Fésüs V, Marosvári D, Kajtár B, et al. TP53 mutation analysis in chronic lymphocytic leukaemia. [A TP53-mutáció-analízis jelentősége krónikus lymphocytás leukaemiában.] Orv Hetil. 2017; 158: 220-228. [Hungarian]

[23] Farooqui MZ, Valdez J, Martyr S, et al. Ibrutinib for previously untreated and relapsed or refractory chronic lymphocytic leukaemia with TP53 aberrations: a phase 2, single-arm trial. Lancet Oncol. 2015; 16: 169-176.

[24] Weston VJ, Oldreive CE, Skowronska A, et al. The PARP inhibitor olaparib induces significant killing of $A T M$-deficient lymphoid tumor cells in vitro and in vivo. Blood 2010; 116: 45784587.

[25] Mous R, Jaspers A, Luijks DM, et al. Detection of p53 dysfunction in chronic lymphocytic leukaemia cells through multiplex quantification of p53 target gene induction. Leukemia 2009; 23 : $1352-1355$.

[26] te Raa GD, Moerland PD, Leeksma AC, et al. Assessment of p53 and ATM functionality in chronic lymphocytic leukemia by multiplex ligation-dependent probe amplification. Cell Death Dis. 2015; 6: el852.

[27] Schwab CJ, Jones LR, Morrison H, et al. Evaluation of multiplex ligation-dependent probe amplification as a method for the detection of copy number abnormalities in B-cell precursor acute lymphoblastic leukemia. Genes Chromosomes Cancer 2010; 49: 1104-1113.

[28] Mullighan CG, Su X, Zhang J, et al. Deletion of IKZFI and prognosis in acute lymphoblastic leukemia. N Engl J Med. 2009; 360: 470-480.

[29] van der Veer A, Waanders E, Pieters R, et al. Independent prognostic value of $B C R-A B L 1$-like signature and $I K Z F I$ deletion, but not high CRLF2 expression, in children with B-cell precursor ALL. Blood 2013; 122: 2622-2629.

[30] Harrison CJ, Moorman AV, Schwab C, et al. An international study of intrachromosomal amplification of chromosome 21 (iAMP21): cytogenetic characterization and outcome. Leukemia 2014; 28: 1015-1021.

[31] Alpar D, de Jong D, Savola S, et al. MLPA is a powerful tool for detecting lymphoblastic transformation in chronic myeloid leukemia and revealing the clonal origin of relapse in pediatric acute lymphoblastic leukemia. Cancer Genet. 2012; 205: 465-469.

[32] Waanders E, Scheijen B, van der Meer LT, et al. The origin and nature of tightly clustered BTGI deletions in precursor B-cell acute lymphoblastic leukemia support a model of multiclonal evolution. PLoS Genet. 2012; 8: e1002533.

[33] Braun M, Pastorczak A, Fendler W, et al. Biallelic loss of $C D K N 2 A$ is associated with poor response to treatment in pediatric acute lymphoblastic leukemia. Leuk Lymphoma 2017; 58: 1162-1171.

[34] Rohde M, Bonn BR, Zimmermann M, et al. Multiplex ligationdependent probe amplification validates LOH6q analyses and enhances insight into chromosome $6 \mathrm{q}$ aberrations in pediatric T-cell lymphoblastic leukemia and lymphoma. Leuk Lymphoma 2015; 56: 1884-1887.

[35] Richter-Pechanska P, Kunz JB, Hof J, et al. Identification of a genetically defined ultra-high-risk group in relapsed pediatric $\mathrm{T}$ lymphoblastic leukemia. Blood Cancer J. 2017; 7: e523.

[36] Kunz JB, Rausch T, Bandapalli OR, et al. Pediatric T-cell lymphoblastic leukemia evolves into relapse by clonal selection, acquisition of mutations and promoter hypomethylation. Haematologica 2015; 100: 1442-1450.

[37] Reyes-Núñez V, Galo-Hooker E, Perez-Romano B, et al. Simultaneous use of multiplex ligation-dependent probe amplification assay and flow cytometric DNA ploidy analysis in patients with acute leukemia. Cytometry B Clin Cytom. 2018; 94: 172-181.

[38] Vázquez-Reyes A, Bobadilla-Morales L, Barba-Barba C, et al. Aneuploidy identification in pre-B acute lymphoblastic leukemia patients at diagnosis by Multiplex Ligation-dependent Probe Amplification (MLPA). Leuk Res. 2017; 59: 117-123.

[39] Pajor L, Szuhai K, Mehes G, et al. Combined metaphase, interphase cytogenetic, and flow cytometric analysis of DNA content 
of pediatric acute lymphoblastic leukemia. Cytometry 1998; 34: 87-94.

[40] Szuhai K, Méhes G, Kosztolányi G, et al. Application of interphase cytogenetics for the determination of changes in the DNA content in acute childhood lymphoid leukemia. [Interfázis citogenetika alkalmazása a DNS-tartalom változásának megítélésére gyermekkori akut lymphoid leukaemiában.] Orv Hetil. 1997; 138: 3111-3119. [Hungarian]

[41] Delfau-Larue MH, Klapper W, Berger F, et al. High-dose cytarabine does not overcome the adverse prognostic value of $C D K$ N2A and TP53 deletions in mantle cell lymphoma. Blood 2015; 126: 604-611.

[42] Alpar D, de Jong D, Holczer-Nagy Z, et al. Multiplex ligationdependent probe amplification and fluorescence in situ hybridization are complementary techniques to detect cytogenetic abnormalities in multiple myeloma. Genes Chromosomes Cancer 2013; 52: 785-793

[43] Boyle EM, Proszek PZ, Kaiser MF, et al. A molecular diagnostic approach able to detect the recurrent genetic prognostic factors typical of presenting myeloma. Genes Chromosomes Cancer 2015; 54: 91-98.

[44] Havranek O, Kleiblova P, Hojny J, et al. Association of germline CHEK2 gene variants with risk and prognosis of non-Hodgkin lymphoma. PLoS ONE 2015; 10: e0140819.

[45] van der Sligte NE, Krumbholz M, Pastorczak A, et al. DNA copy number alterations mark disease progression in paediatric chronic myeloid leukaemia. Br J Haematol. 2014; 166: 250-253.
[46] Donahue AC, Abdool AK, Gaur R, et al. Multiplex ligation-de pendent probe amplification for detection of chromosomal ab normalities in myelodysplastic syndrome and acute myeloid leukemia. Leuk Res. 2011; 35: 1477-1483

[47] Konialis C, Savola S, Karapanou S, et al. Routine application of a novel MLPA-based first-line screening test uncovers clinically relevant copy number aberrations in haematological malignancies undetectable by conventional cytogenetics. Hematology 2014; 19: 217-224.

[48] Kajtár B, Méhes G, Jáksó P, et al. Cytogenetic and molecular monitoring of chronic myeloid leukemia. [A krónikus myeloid leukaemia citogenetikai és molekuláris monitorozása.] Orv Hetil. 2006; 147: 963-970. [Hungarian]

[49] Pajor L. Interphase cytogenetics in oncologic diagnosis. [Az interfázis citogenetika alkalmazási lehetőségei az onkopatológiai diagnosztikában.] Orv Hetil. 1998; 139: 2939-2946. [Hungarian]

[50] Benard-Slagter A, Zondervan I, de Groot K, et al. Digital multiplex ligation-dependent probe amplification for detection of key copy number alterations in T- and B-cell lymphoblastic leukemia. J Mol Diagn. 2017; 19: 659-672.

(Alpár Donát dr., Budapest, Üllői út 26., 1085 e-mail: alpar.donat@med.semmelweis-univ.hu)

\section{MEGHÍ Vó}

\section{A Szent János Kórház és Észak-budai Egyesített Kórházak Tudományos Bizottsága tisztelettel meghívja az érdeklődőket a következő tudományos ülésére.}

Időpont: 2018. április 26. (csütörtök) 14.00 óra

Helyszín: Szent János Kórház Auditóriuma - 1125 Budapest, Diós árok 1-3.

Téma: „Sebészeti betegek komplex ellátása”

\section{Program:}

Üléselnök: Dr. Jánosi András

\section{Lukovich Péter dr.: Megnyitó}

Csiba Borbála dr.: Prehabilitáció: táplálási-team

Csomor Barbara: A fizioterápia szerepe a prehabilitációban

Barok Bianka: Fast-track sebészet koordinálása osztályunkon

Boga Adrienn dr:: Hogyan támogathatja az aneszteziológus a fast track sebészetet?

Schmal Ferenc dr.: A fast track sebészet és az egynapos sebészet határai

Vadinszky Péter dr.: Újdonságok és kihívások a laparoscopos vastagbél sebészetben

(NOSE, fast track, laparoscopos reoperatio)

Nagy Jenő dr., Kovács Márta dr.: Ismeretlen eredetủ masszív alsó gastrointestinalis vérzés fiatal korban

Keszthelyi László dr.: A laparoscopos lépmegtartó sebészetröl egy eset kapcsán

Simon Balázs dr., Dr. Szabó Huba dr:: Crohn-beteg sürgös mütétje. Patológiai diagnózis ileum duplex

Minden érdeklödőt szeretettel várunk! feltéve, hogy az eredeti szerző és a közlés helye, illetve a CC License linkje és az esetlegesen végrehajtott módositások feltüntetésre kerülnek. 